\title{
Exploring reserve lots of Cymbopogon citratus, Aloysia citrodora and Thymus $\times$ citriodorus as improved sources of phenolic compounds
}

\author{
Ingride Rita, Carla Pereira, Lillian Barros*, Isabel C.F.R. Ferreira* \\ Centro de Investigação de Montanha (CIMO), Instituto Politécnico de Bragança, Campus de Santa Apolónia, 5300-253 Bragança, Portugal
}

\section{A R T I C L E I N F O}

\section{Keywords:}

Aromatic plants

Standard and reserve lots

Phenolic composition

HPLC-DAD-ESI/MS

Antioxidant activity

\begin{abstract}
A B S T R A C T
Given the increasing consumers demand for novelty, tea companies have been presenting new added value products such as reserve lots of aromatic plants. Herein, infusions from different lots of three aromatic plants were assessed in terms of phenolic composition (HPLC-DAD-ESI/MS) and antioxidant properties (reducing power, free radical scavenging and lipid peroxidation inhibition capacity). Cymbopogon citratus ( $C$. citratus; main compound 5-O-caffeoylquinic acid) and Aloysia citrodora (A. citrodora; prevalence of verbascoside) reserve lots revealed higher phenolic compounds concentration than the respective standard lots. Thymus $\times$ citriodorus (T. citriodorus; main compound rosmarinic acid) standard lot presented higher amounts of phenolic acids than the reserve lot, nonetheless, total flavonoids and phenolic compounds were not significantly different. The differences between both lots antioxidant activity were more noticeable in C. citratus, with the reserve lot presenting the highest activity. This study provides evidence of the differences between these plants chemical composition and bioactivity depending on the harvesting conditions.
\end{abstract}

\section{Introduction}

Over the past few years, an increasing number of consumers are looking for new food products with distinctive features that provide pleasant moments while affording health benefits (Asioli et al., 2017; McCarthy \& Liu, 2017; Román, Sánchez-Siles, \& Siegrist, 2017; Yasmeen, Fukagawa, \& Wang, 2017). Such products include aromatic plants infusions, which represented, in 2015, a consumption of 5.2 million tons worldwide (Statista, 2015). In Europe, more than 400 different parts of plants are used for the preparation of infusions with a wide range of flavours and, simultaneously, varied health benefits (Schulzki, Nüßlein, \& Sievers, 2017). Owing to this increasing consumption level, and in an attempt to meet consumers' requirements, tea companies have been introducing new added-value products with different characteristics (Gramza-Michałowska, Kulczyński, Xindi, \& Gumienna, 2016). The so-called reserve lots, for example, are prepared through distinct harvesting techniques that differentiate them from standard lots, not only in terms of sensorial characteristics, but also regarding their chemical composition (Rita, Pereira, Barros, SantosBuelga, \& Ferreira, 2016).

Phenolic compounds are an example of plants' secondary metabolites that are affected by harvest conditions, mainly the maturation state, and are considered the most bioactive compounds of medicinal plants infusions and decoctions (Barroso et al., 2016; Costa, Grangeia,
Figueirinha, Figueiredo, \& Batista, 2016; da Silveira, Meinhart, Ballus, \& Godoy, 2014; Fotakis et al., 2016).

Among the most consumed specimens, Cymbopogon citratus (DC.) Stapf (C. citratus), Aloysia citrodora (L'Herit.) Britton (A. citrodora), and Thymus $\times$ citriodorus $\mathrm{L}$. (T. citriodorus) have been widely used for their pleasant taste and health promoting properties (Bensabah, Lamiri, \& Naja, 2015; Coelho et al., 2016; Pereira, Peres, Silva, Domingues, \& Cardoso, 2013). C. citratus, belonging to the Poaceae (Graminae) family, and commonly known as lemongrass, is an Indian and tropical Asia endemic crop that, nowadays, grows worldwide. It has a significant economic value for its diverse industrial applications, such as perfumery, cosmetic, pharmaceutical and food industry (Costa et al., 2016). In herbal medicine, it is used as antibacterial, antifungal, antiprotozoal, anticancer, anti-inflammatory, antioxidant, cardioprotective, antitussive, antiseptic, and antirheumatic (Ajayi, Sadimenko, \& Afolayan, 2016; Chukwuocha, Fernández-Rivera, \& Legorreta-Herrera, 2016; Ekpenyong, Akpan, \& Nyoh, 2015). It has also been used in the prevention of platelet aggregation in the treatment of diabetes, dyslipidemia, gastrointestinal disorders, anxiety, malaria, flu, fever and pneumonia (Costa et al., 2016).

On the other hand, A. citrodora is included in the Verbenaceae family and is commonly known as lemon verbena. It is native from South America and was introduced into Europe in the end of the 17th century, being today cultivated in the Mediterranean and North Africa

\footnotetext{
* Corresponding authors.

E-mail addresses: lillian@ipb.pt (L. Barros), iferreira@ipb.pt (I.C.F.R. Ferreira).
} 
(Marocco) (Bensabah et al., 2015; dos Santos et al., 2017). Its leaves infusion has been widely used in folk medicine for colds, fever, flatulence, colic, diarrhoea, spasms asthma, anxiety, insomnia, and indigestion cases (Carnat, Carnat, Fraisse, \& Lamaison, 1999; dos Santos et al., 2017). Besides these therapeutic characteristics, its leaves are widely appreciated for their characteristic lemony scent, being therefore used in many food preparations, such as fish and poultry dishes, vegetable marinades, salad dressings, jams, puddings, beverages, and sorbets (Funes et al., 2009).

Lastly, T. citriodorus, also known as lemon thyme, belongs to the Lamiaceae family. It is native from Southern Europe and cultivated in Mediterranean area for culinary purposes, due to its pleasant lemon flavour. It has traditionally been used for bronchitis cases and as diaphoretic, but also possesses antimicrobial and antifungal activity (Omidbaigi, Sefidkon, \& Hejazi, 2005).

Given these plants infusions wide consumption, the present study aimed to deepen the scientific knowledge regarding the antioxidant activity and phenolic profile variation between standard and reserve lots.

\section{Materials and methods}

\subsection{Samples and samples preparation}

The dry material of the three species (A. citrodora, T. citriodorus, and C. citratus) used for infusions preparation, both standard and reserve lots, was provided by Cantinho das Aromáticas (organic farmers from Vila Nova de Gaia, Portugal). According to the information provided by the producers, reserve lots were prepared through different harvest procedures, in the hot summer months, being composed by the younger parts (apical leaves) of the species (Rita et al. 2016).

All the infusions were prepared according to the specifications mentioned on the label, except for $C$. citratus, which infusions were prepared in higher concentrations in order to allow the analyses. The infusions of $A$. citrodora, $T$. citriodorus, and $C$. citratus were obtained as follows: $100 \mathrm{~mL}$ of heated distilled water (at 90,85 , and $90^{\circ} \mathrm{C}$, respectively) were added to dry plant material (300, 300, and $900 \mathrm{mg}$, respectively) and the infusions were left to stand (for 7, 7, and $5 \mathrm{~min}$, respectively) until filtration. The obtained infusions were used to perform the different antioxidant activity assays (preparing further dilutions from the stock solution) and to analyse the phenolic profile (after filtration through $0.2 \mu \mathrm{m}$ nylon filters; Whatman ${ }^{\mathrm{TM}}$, Maidstone, UK). Water was treated in a Milli-Q water purification system (TGI Pure Water Systems, Greenville, SC, USA).

\subsection{Analysis of phenolic compounds}

The filtered infusions were submitted to HPLC-DAD-ESI/MS analysis. Chromatographic data were acquired from Dionex Ultimate 3000 UPLC (Thermo Scientific, San Jose, CA, USA) following a procedure previously reported (Bessada, Barreira, Barros, Ferreira, \& Oliveira, 2016). This system consists of a diode array detector coupled to an electrospray ionization mass detector (LC-DAD-ESI/MSn). Waters Spherisorb S3 ODS-2 $\mathrm{C}_{18}$ column $(3 \mu \mathrm{m}, 4.6 \times 150 \mathrm{~mm}$, Waters, Milford, MA, USA) allowed chromatographic separation and the gradient used consisted of the following solvents (A) $0.1 \%$ formic acid (LABSCAN analytical sciences, Gliwice, Poland) in water, and (B) acetonitrile (LAB-SCAN analytical sciences, Gliwice, Poland). The gradient elution applied was: 15\% B (0-5 min), 15\%-20\% B (5-10 min), 20-25\% B (10-20 $\mathrm{min}), 25-35 \%$ B (20-30 $\mathrm{min})$, and $35-50 \%$ B (30-40 $\mathrm{min})$; the column was then re-equilibrated using a flow rate of $0.5 \mathrm{~mL} / \mathrm{min}$. Data were collected simultaneously with a DAD $(280,330$ and $370 \mathrm{~nm})$ and in a mass spectrometer. Negative mode was chosen for MS detection on a Linear Ion Trap LTQ XL mass spectrometer (Thermo Finnigan, San Jose, CA, USA). Sheath gas (nitrogen) was kept on 50 psi. Other parameters settings: $325{ }^{\circ} \mathrm{C}$ of source temperature, $5 \mathrm{kV}$ of spray voltage,
$-20 \mathrm{~V}$ of capillary voltage, $-66 \mathrm{~V}$ of tube lens offset, and 35 arbitrary units of collision energy. The full scan captured the mass between $\mathrm{m} / \mathrm{z}$ 100 and 1500. Xcalibur ${ }^{\circledast}$ data system (Thermo Finnigan, San Jose, CA, USA) was used for data acquisition.

For the identification of phenolic compounds, retention times, UV-VIS and mass spectra were compared with available standards (apigenin 6-C-glucoside $\geq 99 \%$, apigenin 7-O-glucoside $\geq 99 \%$, caffeic acid $\geq 99 \%$, chlorogenic acid $\geq 99 \%$, $p$-coumaric acid $\geq 90 \%$; naringenin $\geq 99 \%$, quercetin 3 -O-glucoside $\geq 99 \%$, rosmarinic acid $\geq 99 \%$ HPLC purity, Extrasynthèse, Genay, France). Literature data were used to tentatively identify the remaining compounds. For the quantitative analysis of phenolic compounds, a calibration curve was obtained by injection of known concentrations $(2.5-100 \mathrm{~g} / \mathrm{ml})$ of different standard compounds. The identified phenolic compounds with unavailable commercial standard were quantified via calibration curve of the most similar standard available. The results were expressed as $\mu \mathrm{g} / \mathrm{mL}$ of infusion.

\subsection{Evaluation of the antioxidant activity}

The antioxidant activity of the infusions prepared from standard and reserve lots was evaluated trough four different assays, DPPH radicalscavenging activity, reducing power, $\beta$-carotene bleaching inhibition and lipid peroxidation inhibition by TBARS assay, as previously described by the authors (Rita et al. 2016). The results were converted into $\mathrm{EC}_{50}$ values $(\mathrm{mg} / \mathrm{mL})$, which represent the infusion concentration that presents the capacity to provide $50 \%$ of antioxidant activity or 0.5 of absorbance in the reducing power assay. Trolox (6-hydroxy-2,5,7,8tetramethylchroman-2-carboxylic acid; Sigma, St. Louis, MO, USA) was used as positive control.

\subsection{Statistical analysis}

All the assays were carried out using triplicates of the samples with different concentrations and respective spectrophotometric measurements. The results were expressed as mean values and standard deviations (SD) and analysed using a Student's $t$-test in order to determine the significant difference among two different samples, with a $p$-value of 0.05 . When the $p$-value was lower than 0.05 , significant differences between samples were considered. Furthermore, a Pearson's correlation analysis between the antioxidant activity and all the identified compounds was carried out, with a $95 \%$ confidence level. These statistical treatments were carried out using SPSS v. 23.0 program (IBM Corp., Armonk, NY, USA).

\section{Results and discussion}

\subsection{Phenolic compounds}

The identification of individual phenolic compounds was carried out considering their retention times, whenever possible in comparison with commercially available standards, and both UV and MS spectra. The phenolic profile of the samples revealing the highest contents of phenolic compounds is shown in Fig. 1. Data obtained by HPLC-DADESI/MS analysis (retention time, $\lambda_{\max }$, pseudomolecular ion, main fragment ions in $\mathrm{MS}^{2}$ ), phenolic compounds identification, and respective quantification are present in Tables 1-3.

Regarding $C$. citratus, the standard and reserve lots revealed similar phenolic profiles in terms of detected compounds, but the reserve lot presented significantly higher concentrations than the standard lot, with a total amount of 88 and $11.1 \mu \mathrm{g} / \mathrm{mL}$, respectively. Both lots revealed a prevalence of flavonoids, with the highest contributions of luteolin 2"-O-deoxyhexosyl-6-C-glucoside and luteolin 6-C-pentosyl-8$\mathrm{C}$-pentoside, but the most abundant compound was 5-O-caffeoylquinic acid in both lots. All the identified compounds were previously found and described by our research group in C. citratus (Roriz, Barros, 


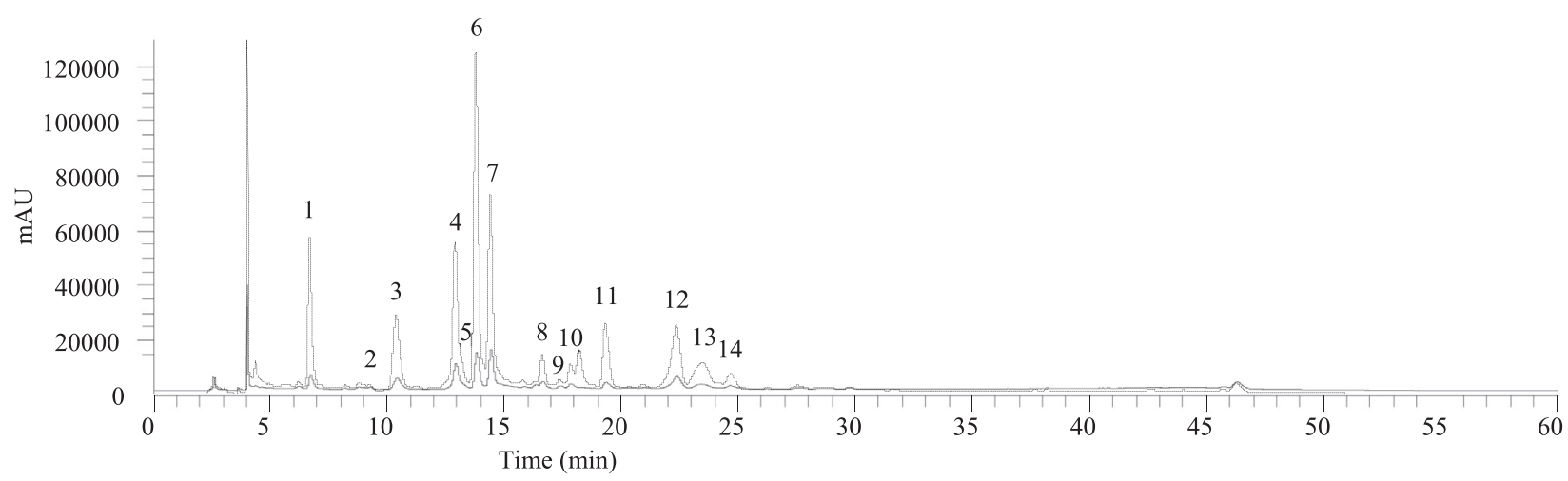

A

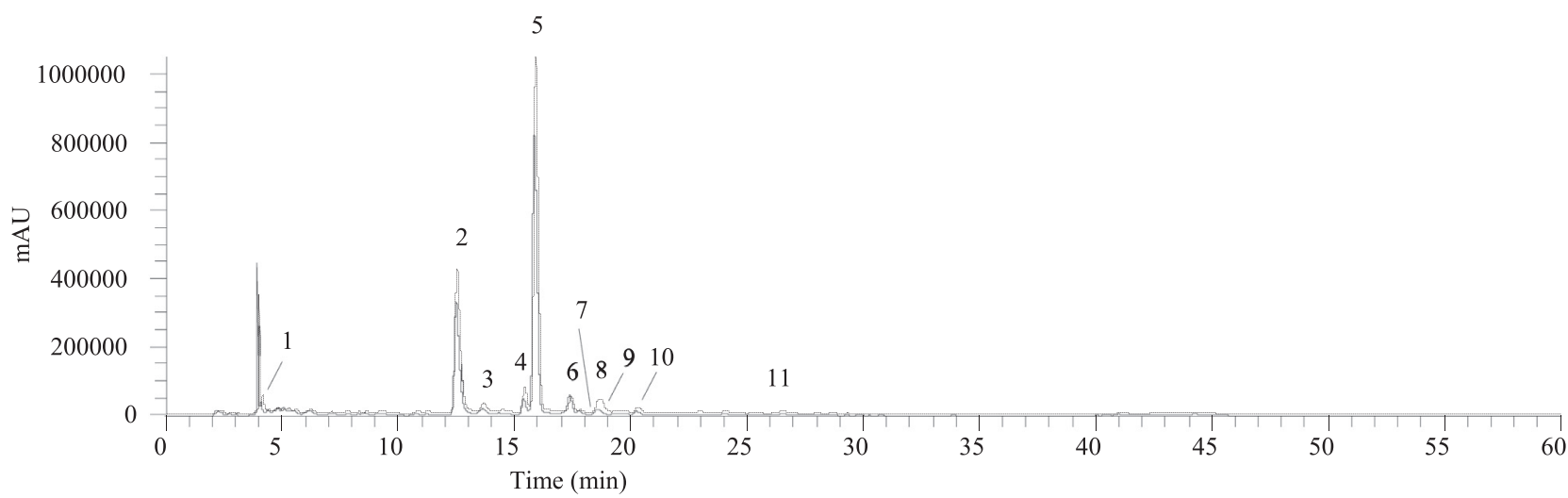

B

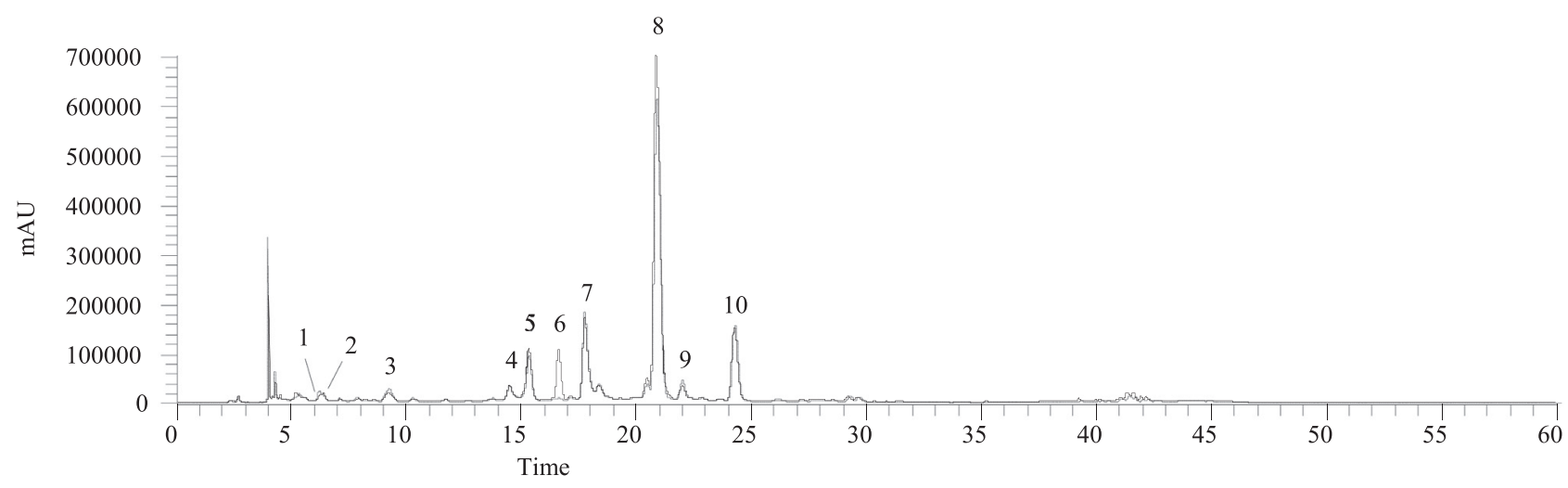

C

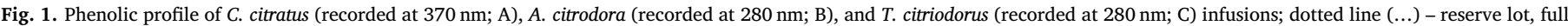
line $(-)$ - standard lot. Peak numbering is in accordance with Tables 1-3.

Carvalho, Santos-Buelga, \& Ferreira, 2014), where the major flavonoid detected was also luteolin 2"-O-deoxyhexosyl-6-C-glucoside but, contrarily to the results obtained in the present study, in higher concentrations than 5-O-caffeoylquinic acid. This variation could be attributed to the different harvest conditions, given the fact that hydroxycinnamic acids appear among the compounds that present the highest variability over spring-summer months (Costa et al., 2016).

In the case of $A$. citrodora, similar observations could be made, with the reserve lot $(230 \mu \mathrm{g} / \mathrm{mL})$ presenting higher concentrations of phenolic compounds than the standard lot (182 $\mu \mathrm{g} / \mathrm{mL}) . p$-Coumaric acid was the only phenolic acid detected, in concentrations of 1.65 and $1.91 \mu \mathrm{g} / \mathrm{mL}$ in standard and reserve lots, respectively. Flavonoids and caffeoyl phenylethanoid derivatives were present in similar amounts in both lots, but in slightly higher concentrations in the reserve lot. In a study where we previously assessed the phenolic composition of $\mathrm{A}$. citrodora infusions (Pereira, Pimenta, et al., 2017), the amounts of total caffeoyl derivatives $(146.0 \mu \mathrm{g} / \mathrm{mL})$ were higher than in the infusions studied herein $(86.1$ and $112 \mu \mathrm{g} / \mathrm{mL}$ for standard and reserve lots, 


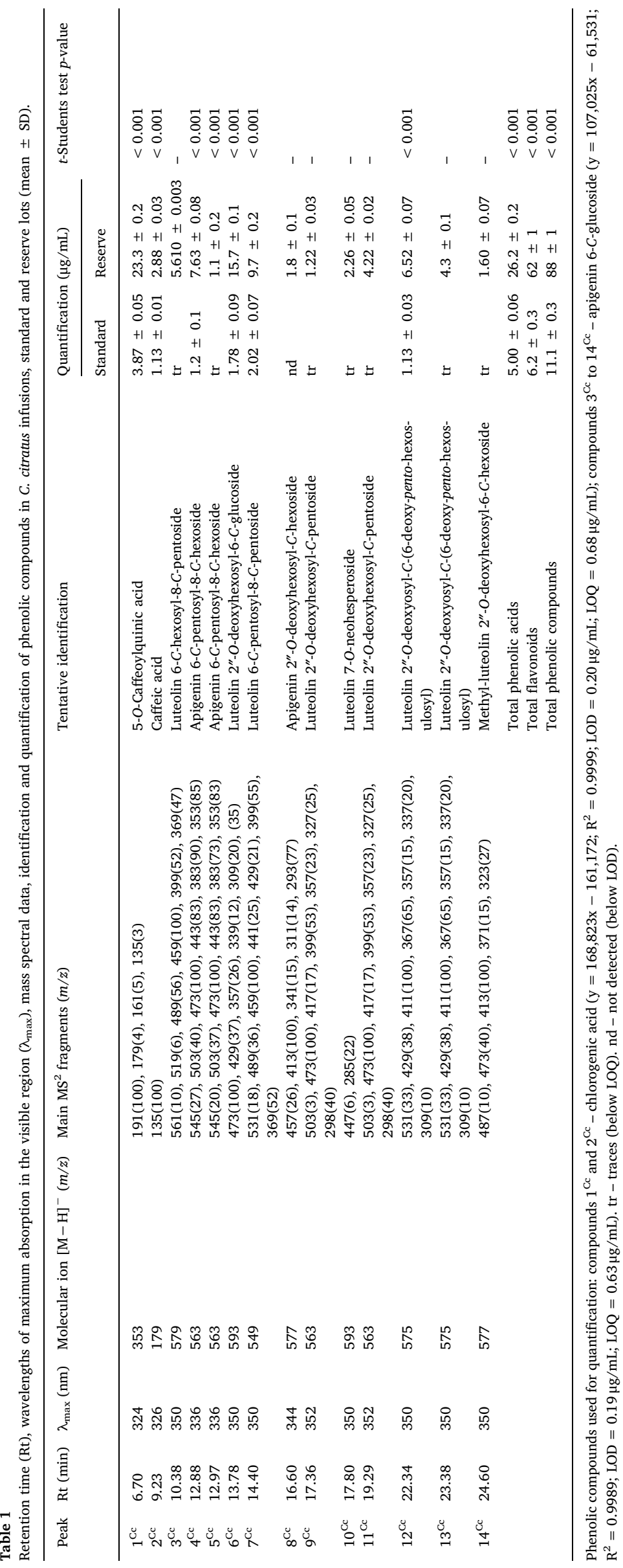


Table 2

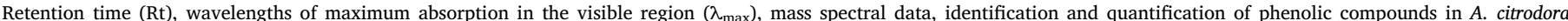
infusions, standard and reserve lots (mean $\pm \mathrm{SD}, \mathrm{n}=9$ ).

\begin{tabular}{|c|c|c|c|c|c|c|c|c|}
\hline \multirow[t]{2}{*}{ Peak } & \multirow[t]{2}{*}{ Rt (min) } & \multirow{2}{*}{$\begin{array}{l}\lambda_{\max } \\
(\mathrm{nm})\end{array}$} & \multirow{2}{*}{$\begin{array}{l}\text { Pseudomolecular ion }[\mathrm{M}-\mathrm{H}]^{-} \\
(\mathrm{m} / \mathrm{z})\end{array}$} & \multirow[t]{2}{*}{$\operatorname{MS}^{2}(m / z)$} & \multirow[t]{2}{*}{ Tentative identification } & \multicolumn{2}{|c|}{ Quantification $(\mu \mathrm{g} / \mathrm{mL})$} & \multirow{2}{*}{$\begin{array}{l}t \text {-Students test } p \text { - } \\
\text { value }\end{array}$} \\
\hline & & & & & & Standard & Reserve & \\
\hline $1^{\mathrm{Ac}}$ & 4.18 & 280 & 461 & $315(8), 135(28)$ & Verbascoside & $3.1 \pm 0.1$ & $3.91 \pm 0.10$ & $<0.001$ \\
\hline $2^{\mathrm{Ac}}$ & 12.54 & 344 & 637 & $351(100), 285(89)$ & Luteolin 7-O-diglucuronide & $67.7 \pm 0.5$ & $87.70 \pm 1.02$ & $<0.001$ \\
\hline $3^{\mathrm{Ac}}$ & 13.68 & 314 & 163 & $119(100)$ & $p$-Coumaric acid & $1.65 \pm 0.04$ & $1.91 \pm 0.04$ & $<0.001$ \\
\hline $4^{\mathrm{Ac}}$ & 15.44 & 338 & 621 & $351(100), 269(20)$ & Apigenin 7-O-diglucuronide & $8.04 \pm 0.06$ & $9.99 \pm 0.08$ & $<0.001$ \\
\hline $5^{\mathrm{Ac}}$ & 15.90 & 330 & 623 & $461(18), 315(5)$ & Verbascoside & $73 \pm 1$ & $93 \pm 1$ & $<0.001$ \\
\hline $6^{\mathrm{Ac}}$ & 17.42 & 350 & 651 & $351(100), 299(5)$ & Chrysoeriol 7-O-diglucuronide & $12.6 \pm 0.2$ & $11.1 \pm 0.1$ & $<0.001$ \\
\hline $7^{\mathrm{Ac}}$ & 18.60 & 330 & 623 & $461(18), 315(5)$ & Isoverbascoside & $2.6 \pm 0.01$ & $4.4 \pm 0.1$ & $<0.001$ \\
\hline $8^{\mathrm{Ac}}$ & 18.68 & 330 & 623 & 461(15), 315(10) & Forsythoside & $2.46 \pm 0.01$ & $4.50 \pm 0.03$ & $<0.001$ \\
\hline $9^{\mathrm{Ac}}$ & 18.79 & 350 & 491 & $315(100), 300(23)$ & Isorhamnetin 3-O-glucuronide & $5.65 \pm 0.03$ & $7.70 \pm 0.04$ & $<0.001$ \\
\hline $10^{\mathrm{Ac}}$ & 20.29 & 330 & 637 & $\begin{array}{l}491(5), 461(60) \\
315(13)\end{array}$ & Eukovoside & $2.6 \pm 0.2$ & $3.37 \pm 0.05$ & $<0.001$ \\
\hline \multirow[t]{5}{*}{$11^{\mathrm{Ac}}$} & 26.52 & 330 & 651 & 505(7), 475(22) & Martinoside & $2.14 \pm 0.05$ & $2.59 \pm 0.04$ & $<0.001$ \\
\hline & & & & & $\begin{array}{l}\text { Total caffeoyl phenylethanoid } \\
\text { derivatives }\end{array}$ & $86.1 \pm 1$ & $112 \pm 2$ & $<0.001$ \\
\hline & & & & & Total phenolic acids & $1.65 \pm 0.04$ & $1.91 \pm 0.04$ & $<0.001$ \\
\hline & & & & & Total flavonoids & $94.0 \pm 0.8$ & $117 \pm 1$ & $<0.001$ \\
\hline & & & & & Total phenolic compounds & $182 \pm 2$ & $230 \pm 3$ & $<0.001$ \\
\hline
\end{tabular}

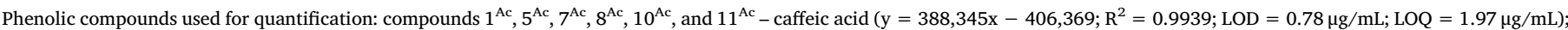

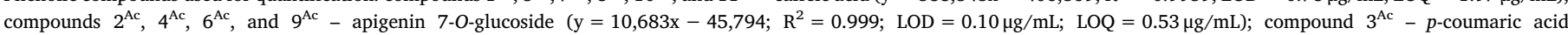
( $\left.\mathrm{y}=301,950 \mathrm{x}+6966,7 ; \mathrm{R}^{2}=0.9999 ; \mathrm{LOD}=0.68 \mu \mathrm{g} / \mathrm{mL} ; \mathrm{LOQ}=1.61 \mu \mathrm{g} / \mathrm{mL}\right)$. Total caffeoyl phenylethanoid derivatives includes verbasoside.

respectively), as also the concentration of total phenolic compounds $(241 \mu \mathrm{g} / \mathrm{mL})$. All the compounds detected were coincident with those identified in a previously studied sample (Pereira, Pimenta, et al., 2017), with luteolin 7-O-diglucuronide and verbascoside as the major compounds found. In another study performed by our research group, a similar phenolic profile was obtained for hydromethanolic extracts of the plant, where the most abundant compounds were also common to those detected herein (Pereira, Barros, et al., 2017).

Contrarily to the results obtained for $C$. citratus and A. citrodora, the infusions prepared from the standard lots of $T$. citriodorus revealed slightly higher concentrations of phenolic compounds than those obtained from the reserve lots, with a total amount of 170 and $154 \mu \mathrm{g} / \mathrm{mL}$, respectively. Both lots revealed a prevalence of phenolic acids (111 and $92 \mu \mathrm{g} / \mathrm{mL}$ for standard and reserve lots, respectively), with rosmarinic acid as the most abundant one, followed by lithospermic acid A and rosmarinic acid hexoside. Regarding flavonoids, luteolin 7-O-glucuronide, apigenin 7-O-glucuronide, eriodictyol $O$-glucuronide, and quercetin $O$-glucuronide were the major molecules identified. The compounds detected in these samples have been previously found and identified by our research group in Thymus vulgaris L. infusions, decoctions, hydroalcoholic, and methanolic extracts (Martins et al., 2015; Pereira, Barros, et al., 2016; Pereira, Pimenta, et al., 2016). In general, luteolin 7-O-glucuronide and rosmarinic acid were the most abundant compounds in the different studied extracts, as in the standard and

Table 3

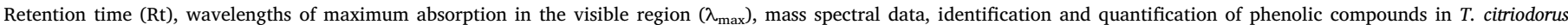
infusions, standard and reserve lots (mean $\pm S D, n=9$ ).

\begin{tabular}{|c|c|c|c|c|c|c|c|c|}
\hline \multirow[t]{2}{*}{ Peak } & \multirow[t]{2}{*}{ Rt (min) } & \multirow[t]{2}{*}{$\lambda_{\max }(\mathrm{nm})$} & \multirow{2}{*}{$\begin{array}{l}\text { Molecular ion }[\mathrm{M}-\mathrm{H}]^{-} \\
(\mathrm{m} / \mathrm{z})\end{array}$} & \multirow[t]{2}{*}{$\operatorname{MS}^{2}(m / z)$} & \multirow[t]{2}{*}{ Tentative identification } & \multicolumn{2}{|c|}{ Quantification $(\mu \mathrm{g} / \mathrm{mL})$} & \multirow{2}{*}{$\begin{array}{l}t \text {-Students test } p \text { - } \\
\text { value }\end{array}$} \\
\hline & & & & & & Standard & Reserve & \\
\hline $1^{\mathrm{Tc}}$ & 6.24 & 320 & 341 & 179(100), 135(88) & Caffeic acid hexoside & $2.09 \pm 0.04$ & $2.69 \pm 0.04$ & $<0.001$ \\
\hline $2^{\mathrm{Tc}}$ & 6.38 & 282,327 & 611 & 449(100), 287(14) & Eriodictyol $O$-dihexoside & $\operatorname{tr}$ & $\operatorname{tr}$ & - \\
\hline $3^{\mathrm{Tc}}$ & 9.13 & 338 & 593 & 473(20), 383(33), 353(27), 297(5) & $\begin{array}{l}\text { Apigenin } 6,8-\text { di- } C \text { - } \\
\text { glucoside }\end{array}$ & $\operatorname{tr}$ & $1.05 \pm 0.06$ & - \\
\hline $4^{\mathrm{Tc}}$ & 14.50 & 340 & 477 & $301(100)$ & Quercetin $O$-glucuronide & $5.68 \pm 0.02$ & $5.65 \pm 0.03$ & 0.242 \\
\hline $5^{\mathrm{Tc}}$ & 15.33 & 285,331 & 463 & $287(100)$ & Eriodictyol $O$-glucuronide & $6.17 \pm 0.09$ & $5.3 \pm 0.1$ & $<0.001$ \\
\hline $6^{\mathrm{Tc}}$ & 16.60 & 322 & 521 & $\begin{array}{l}359(100), 197(13), 179(36), \\
161(62), 135(21)\end{array}$ & Rosmarinic acid hexoside & $11.7 \pm 0.3$ & $4.24 \pm 0.06$ & $<0.001$ \\
\hline $7^{\mathrm{Tc}}$ & 17.74 & 348 & 461 & $285(100)$ & Luteolin 7-O-glucuronide & $39 \pm 1$ & $41.2 \pm 0.9$ & 0.018 \\
\hline $8^{\mathrm{Tc}}$ & 20.85 & 330 & 359 & $\begin{array}{l}\text { 197(17), 179(35), 161(100), } \\
\text { 135(29) }\end{array}$ & Rosmarinic acid & $78 \pm 2$ & $66 \pm 2$ & $<0.001$ \\
\hline $9^{\mathrm{Tc}}$ & 21.99 & 336 & 445 & $269(100)$ & Apigenin 7-O-glucuronide & $7.53 \pm 0.01$ & $9.2 \pm 0.2$ & $<0.001$ \\
\hline \multirow[t]{4}{*}{$10^{\mathrm{Tc}}$} & 24.25 & $\begin{array}{l}290, \\
326 \mathrm{sh}\end{array}$ & 537 & $\begin{array}{l}\text { 493(50), 359(17), 295(33), 179(75), } \\
\text { 135(100) }\end{array}$ & Lithospermic acid A & $19.4 \pm 0.6$ & $18.8 \pm 0.7$ & 0.138 \\
\hline & & & & & Total phenolic acids & $111 \pm 3$ & $92 \pm 2$ & $<0.001$ \\
\hline & & & & & Total flavonoids & $58 \pm 1$ & $62 \pm 1$ & 0.008 \\
\hline & & & & & $\begin{array}{l}\text { Total phenolic } \\
\text { compounds }\end{array}$ & $170 \pm 4$ & $154 \pm 4$ & 0.002 \\
\hline
\end{tabular}

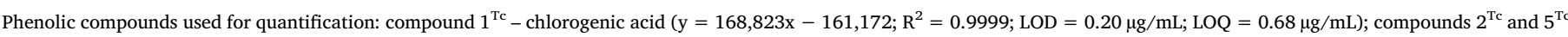

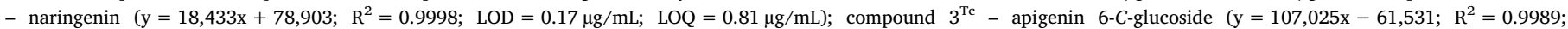

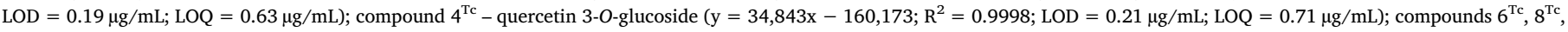

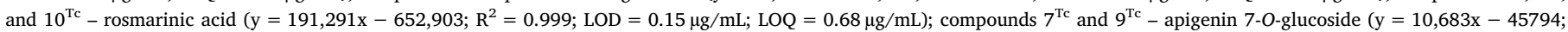
$\mathrm{R}^{2}=0.999 ; \mathrm{LOD}=0.10 \mu \mathrm{g} / \mathrm{mL} ; \mathrm{LOQ}=0.53 \mu \mathrm{g} / \mathrm{mL}$ ). $\mathrm{tr}$ - traces (below LOQ). 
Table 4

Antioxidant activity of $C$. citratus, $A$. citriodira, and $T$. citriodorus standard and reserve lots infusions, expressed as $\mathrm{EC}_{50} \mathrm{values}(\mathrm{mg} / \mathrm{mL}, \mathrm{mean} \pm \mathrm{SD}, \mathrm{n}=9$ ).

\begin{tabular}{|c|c|c|c|c|}
\hline & \multirow{2}{*}{$\begin{array}{l}\text { Reducing power } \\
\text { Ferricyanide/Prussian blue }\end{array}$} & \multicolumn{2}{|l|}{ Radical scavenging activity } & \multirow{2}{*}{$\begin{array}{l}\text { Lipid peroxidation inhibition } \\
\text { TBARS }\end{array}$} \\
\hline & & DPPH scavenging activity & $\beta$-carotene/linoleate & \\
\hline C. citratus standard lot & $2.33 \pm 0.05$ & $3.49 \pm 0.03$ & $3.66 \pm 0.09$ & $0.75 \pm 0.03$ \\
\hline C. citratus reserve lot & $1.01 \pm 0.01$ & $1.43 \pm 0.06$ & $2.01 \pm 0.03$ & $0.37 \pm 0.01$ \\
\hline Student's $t$-test $p$-value & $<0.001$ & $<0.001$ & $<0.001$ & $<0.001$ \\
\hline A. citrodora standard lot & $0.205 \pm 0.001$ & $0.39 \pm 0.05$ & $0.93 \pm 0.02$ & $0.082 \pm 0.001$ \\
\hline A. citrodora reserve lot & $0.169 \pm 0.001$ & $0.25 \pm 0.01$ & $0.92 \pm 0.01$ & $0.088 \pm 0.001$ \\
\hline Student's $t$-test $p$-value & $<0.001$ & 0.013 & 0.350 & 0.002 \\
\hline T. citriodorus standard lot & $0.228 \pm 0.003$ & $0.34 \pm 0.01$ & $1.01 \pm 0.06$ & $0.118 \pm 0.001$ \\
\hline T. citriodorus reserve lot & $0.393 \pm 0.002$ & $0.32 \pm 0.02$ & $0.73 \pm 0.03$ & $0.117 \pm 0.001$ \\
\hline Student's $t$-test $p$-value & $<0.001$ & 0.251 & 0.035 & 0.112 \\
\hline
\end{tabular}

Trolox $\mathrm{EC}_{50}$ values: $41 \mu \mathrm{g} / \mathrm{mL}$ (reducing power), $42 \mu \mathrm{g} / \mathrm{mL}$ (DPPH scavenging activity), $18 \mu \mathrm{g} / \mathrm{mL}$ ( $\beta$-carotene bleaching inhibition) and $23 \mu \mathrm{g} / \mathrm{mL}$ (TBARS inhibition).

reserve lots of $T$. citriodorus assessed in the present work.

\subsection{Antioxidant activity}

The antioxidant activity results obtained for the standard and reserve lots of $C$. citratus, $A$. citrodora, and $T$. citriodorus, expressed as $\mathrm{EC}_{50}$ values, are present in Table 4. C. citratus reserve lot $(0.37-2.01 \mathrm{mg} / \mathrm{mL})$ revealed a higher antioxidant activity than the standard lot $(0.75-3.66 \mathrm{mg} / \mathrm{mL})$, with lower $\mathrm{EC}_{50}$ values in the four assays performed, which is in accordance with its higher phenolic compounds concentration.

Regarding A. citrodora lots, the differences between the results obtained in the four assays were not statistically significant, with the exception of the reducing power, where the reserve lot exhibited better results $\left(\mathrm{EC}_{50}\right.$ values of 0.169 and $0.205 \mathrm{mg} / \mathrm{mL}$ for the reserve and the standard lots, respectively).

Similarly, for T. citriodorus infusions, the standard and reserve lots gave similar results of antioxidant capacity, except for the reducing power assay, but with the standard lot revealing the highest activity (EC 50 values of 0.228 and $0.393 \mathrm{mg} / \mathrm{mL}$ for the standard and reserve lots, respectively), which could be explained by its higher concentration of phenolic compounds.

All the $\mathrm{EC}_{50}$ values obtained for the infusions were higher than those of the positive control (trolox), nevertheless, these results were obtained for the infusions prepared according to the label specifications and, despite their high concentration value, the $\mathrm{EC}_{50}$ values were all lower than the recommended concentration $(3 \mathrm{mg} / \mathrm{mL})$. As the only exception, the standard lot of $C$. citratus presented $\mathrm{EC}_{50}$ values slightly higher than the recommended concentration in the DPPH scavenging activity $(3.49 \mathrm{mg} / \mathrm{mL})$ and $\beta$-carotene bleaching inhibition $(3.66 \mathrm{mg}$ / $\mathrm{mL}$ ) assays.

Correlation factors between the antioxidant activity and the phenolic composition were obtained, using a Pearson's correlation analysis, after verifying the normality through a Shapiro-Wilk test. Regarding $C$. citratus infusions, higher statistically significant correlations were found between the total phenolic compounds amount and the $\mathrm{EC}_{50}$ values obtained in DPPH scavenging activity $\left(R^{2}=-0.886, p\right.$-values $\left.=0.019\right)$ and reducing power $\left(R^{2}=-0.999, p\right.$-values $\left.\leq 0.001\right)$ assays; otherwise, lower correlations were obtained for $\beta$-carotene bleaching inhibition $\left(R^{2}=-0.600, p\right.$-values $\left.=0.208\right)$ and lipid peroxidation inhibition by TBARS assays $\left(R^{2}=-0.771, \quad p\right.$-values $\left.=0.072\right)$. The antioxidant capacity of $A$. citrodora infusions was significantly correlated to the concentration of total phenolic compounds regarding DPPH scavenging activity $\left(R^{2}=-0.892, p\right.$-values $\left.=0.017\right)$, reducing power $\left(R^{2}=-0.997, p\right.$-values $\left.<0.001\right)$, and TBARS assays $\left(R^{2}=-0.946\right.$, $p$-values $=0.004)$, contrarily to the $\beta$-carotene bleaching inhibition test $\left(R^{2}=-0.475, p\right.$-values $\left.=0.341\right)$. In what concerns $T$. citriodorus infusions, the total concentrations of phenolic compounds were highly correlated to the reducing power $\left(R^{2}=-0.959, p\right.$-values $\left.=0.003\right)$ and $\beta$-carotene bleaching inhibition $\left(R^{2}=-0.880, \quad p\right.$-values $\left.=0.021\right)$ assays, while for the TBARS assays $\left(R^{2}=-0.650, p\right.$-values $\left.=0.162\right)$, lower correlation factors were obtained. The DPPH scavenging activity $\left(R^{2}=-0.422, p\right.$-values $\left.=0.405\right)$ was not correlated with the phenolic compounds, meaning that other compounds (e.g. triterpenoids, vitamins or other organic compounds) might be related to the scavenging effect revealed by this species.

\section{Conclusion}

In general, the samples presenting the highest concentration of phenolic compounds also revealed the highest antioxidant activity. The infusions prepared from reserve lots of $C$. citratus and A. citrodora revealed higher amounts of total phenolic acids and flavonoids than those obtained from standard lots. In the case of $T$. citriodorus infusions, the standard and reserve lots did not reveal significant differences regarding the total flavonoids and total phenolic compounds concentration. The results obtained in this study will allow consumers to make a conscientious choice between the two categories (standard and reserve lots), not only based on their sensory characteristics, but also on their bioactive potential.

\section{Acknowledgments}

The authors are grateful to the Foundation for Science and Technology (FCT, Portugal) and FEDER under Programme PT2020 for financial support to CIMO (UID/AGR/00690/2013); to FCT for L. Barros research contract; to FCT for the grant attributed to C. Pereira (SFRH/BPD/122650/2016) through the Programa Operacional Capital Humano (POCH) supported by the European Social Fund and National Funds of MCTES (Ministério da Ciência, Tecnologia, e Ensino Superior). The authors are grateful to FEDER-Interreg España-Portugal programme for financial support through the project 0377_Iberphenol_6_E.

\section{References}

Ajayi, E. O., Sadimenko, A. P., \& Afolayan, A. J. (2016). GC-MS evaluation of Cymbopogon citratus (DC) Stapf oil obtained using modified hydrodistillation and microwave extraction methods. Food Chemistry, 209, 262-266.

Asioli, D., Aschemann-Witzel, J., Caputo, V., Vecchio, R., Annunziata, A., Næs, T., \& Varela, P. (2017). Making sense of the "clean label" trends: A review of consumer food choice behavior and discussion of industry implications. Food Research International [In press].

Barroso, M. F., Ramalhosa, M. J., Alves, R. C., Dias, A., Soares, C. M. D., Oliva-Teles, M. T., \& Delerue-Matos, C. (2016). Total antioxidant capacity of plant infusions: Assessment using electrochemical DNA-based biosensor and spectrophotometric methods. Food Control, 68, 153-161.

Bensabah, F., Lamiri, A., \& Naja, J. (2015). Effect of purified wastewater from the city of Settat (Morocco) on the quality of Lippia citriodora essential oil and infusion. Journal of the Saudi Society of Agricultural Sciences, 14, 101-108.

Bessada, S. M. F., Barreira, J. C. M., Barros, L., Ferreira, I. C. F. R., \& Oliveira, M. B. P. P. (2016). Phenolic profile and antioxidant activity of Coleostephus myconis (L.) Rchb.f. An underexploited and highly disseminated species. Industrial Crops and Products, 89 45-51.

Carnat, A., Carnat, A., Fraisse, D., \& Lamaison, J. (1999). The aromatic and polyphenolic 
composition of lemon verbena tea. Fitoterapia, 70, 44-49.

Chukwuocha, U. M., Fernández-Rivera, O., \& Legorreta-Herrera, M. (2016). Exploring the antimalarial potential of whole Cymbopogon citratus plant therapy. Journal of Ethnopharmacology, 193, 517-523.

Coelho, M., Rocha, C., Cunha, L. M., Cardoso, L., Alves, L., Lima, R. C., ... Pintado, M. (2016). Influence of harvesting factors on sensory attributes and phenolic and aroma compounds composition of Cymbopogon citratus leaves infusions. Food Research International, 89, 1029-1037.

Costa, G., Grangeia, H., Figueirinha, A., Figueiredo, I. V., \& Batista, M. T. (2016). Influence of harvest date and material quality on polyphenolic content and antioxidant activity of Cymbopogon citratus infusion. Industrial Crops and Products, 83, 738-745.

da Silveira, T. F. F., Meinhart, A. D., Ballus, C. A., \& Godoy, H. T. (2014). The effect of the duration of infusion, temperature, and water volume on the rutin content in the preparation of mate tea beverages: An optimization study. Food Research International, 60, 241-245.

dos Santos, A. C., Sutili, F. J., Heinzmann, B. M., Cunha, M. A., Brusque, I. C. M., Baldisserotto, B., \& Zeppenfeld, C. C. (2017). Aloysia triphylla essential oil as additive in silver catfish diet: Blood response and resistance against Aeromonas hydrophila infection. Fish \& Shellfish Immunology, 62, 213-216.

Ekpenyong, C. E., Akpan, E., \& Nyoh, A. (2015). Ethnopharmacology, phytochemistry, and biological activity of Cymbopogon citratus (DC.) Stapf extracts. Chinese Journal of Natural Medicines, 13, 321-337.

Fotakis, C., Tsigrimani, D., Tsiaka, T., Lantzouraki, D. Z., Strati, I. F., Makris, C., .. Zoumpoulakis, P. (2016). Metabolic and antioxidant profiles of herbal infusions and decoctions. Food Chemistry, 211, 963-971.

Funes, L., Fernández-Arroyo, S., Laporta, O., Pons, A., Roche, E., Segura-Carretero, A.... Micol, V. (2009). Correlation between plasma antioxidant capacity and verbascoside levels in rats after oral administration of lemon verbena extract. Food Chemistry, 117, 589-598.

Gramza-Michałowska, A., Kulczyński, B., Xindi, Y., \& Gumienna, M. (2016). Research on the effect of culture time on the kombucha tea beverage's antiradical capacity and sensory value. Acta Scientiarum Polonorum Technologia Alimentaria, 15, 447-457.

Martins, N., Barros, L., Santos-Buelga, C., Silva, S., Henriques, M., \& Ferreira, I. C. F. R. (2015). Decoction, infusion and hydroalcoholic extract of cultivated thyme: Antioxidant and antibacterial activities, and phenolic characterisation. Food Chemistry, 167, 131-137.

McCarthy, B., \& Liu, H. B. (2017). Food waste and the "green" consumer. Australasian Marketing Journal (AMJ), 25, 126-132.

Omidbaigi, R., Sefidkon, F., \& Hejazi, M. (2005). Essential oil composition of Thymus citriodorus L. cultivated in Iran. Flavour and Fragrance Journal, 20, 237-238.
Pereira, E., Barros, L., Antonio, A., Cabo Verde, S., Santos-Buelga, C., Ferreira, I., \& Rodrigues, P. (2017a). Is gamma radiation suitable to preserve phenolic compounds and to decontaminate mycotoxins in aromatic plants? A case-study with Aloysia citrodora Paláu. Retrieved from Molecules, 22, 347-359. http://www.ncbi.nlm.nih. gov/pubmed/28241497.

Pereira, E., Barros, L., Antonio, A. L., Cabo Verde, S., Santos-Buelga, C., \& Ferreira, I. C. F. R. (2016a). Infusions from Thymus vulgaris L. treated at different gamma radiation doses: Effects on antioxidant activity and phenolic composition. LWT - Food Science and Technology, 74, 34-39.

Pereira, E., Pimenta, A. I., Calhelha, R. C., Antonio, A. L., Barros, L., Santos-Buelga, C., ... Ferreira, I. C. F. R. (2017b). Infusions of gamma irradiated Aloysia citrodora L. and Mentha $\times$ piperita L.: Effects on phenolic composition, cytotoxicity, antibacterial and virucidal activities. Industrial Crops and Products, 97, 582-590.

Pereira, E., Pimenta, A. I., Calhelha, R. C., Antonio, A. L., Verde, S. C., Barros, L., .. Ferreira, I. C. F. R. (2016b). Effects of gamma irradiation on cytotoxicity and phenolic compounds of Thymus vulgaris L. and Mentha $\times$ piperita L. LWT - Food Science and Technology, 71, 370-377.

Pereira, O. R., Peres, A. M., Silva, A. M. S., Domingues, M. R. M., \& Cardoso, S. M. (2013). Simultaneous characterization and quantification of phenolic compounds in Thymus $\times$ citriodorus using a validated HPLC-UV and ESI-MS combined method. Food Research International, 54, 1773-1780.

Rita, I., Pereira, C., Barros, L., Santos-Buelga, C., \& Ferreira, I. C. F. R. (2016). Mentha spicata L. infusions as sources of antioxidant phenolic compounds: Emerging reserve lots with special harvest requirements. Food \& Function, 7, 4188-4192.

Román, S., Sánchez-Siles, L. M., \& Siegrist, M. (2017). The importance of food naturalness for consumers: Results of a systematic review. Trends in Food Science \& Technology, 67 44-57.

Roriz, C. L., Barros, L., Carvalho, A. M., Santos-Buelga, C., \& Ferreira, I. C. F. R. (2014). Pterospartum tridentatum, Gomphrena globosa and Cymbopogon citratus: A phytochemical study focused on antioxidant compounds. Food Research International, 62, 684-693.

Schulzki, G., Nüßlein, B., \& Sievers, H. (2017). Transition rates of selected metals determined in various types of teas (Camellia sinensis L. Kuntze) and herbal/fruit infusions. Food Chemistry, 215, 22-30.

Statista, The Statistics Portal (2015). Global production and exports of tea from 2004 to 2015 (in million metric tons). https://www.statista.com/statistics/264183/globalproduction-and-exports-of-tea-since-2004/ (acceded 12 September 2017).

Yasmeen, R., Fukagawa, N. K., \& Wang, T. T. (2017). Establishing health benefits of bioactive food components: A basic research scientist's perspective. Current Opinion in Biotechnology, 44, 109-114. 